\title{
WEB-Based Decision Support System for Mobile Selection using the Simple Additive Weighting Method
}

\author{
Agnesdea Meiti Suroso
}

Program Studi Teknik Informatika, Jurusan Teknik Informatika, Fakultas Sains dan Teknologi, Universitas Sanata Darma Yogyakarta

\begin{tabular}{|c|c|}
\hline Article Info & ABSTRACT \\
\hline Article history: & Along with the development of mobile phones in Indonesia, people \\
\hline $\begin{array}{l}\text { Received: } 16 / 05 / 2021 \\
\text { Revised: } 13 / 07 / 2021 \\
\text { Accepted: } 04 / 09 / 2021 \\
\text { Available online } 30 / 09 / 2021\end{array}$ & $\begin{array}{l}\text { from various professions are very dependent on mobile phones. } \\
\text { Problems arise when these developments are not accompanied by a } \\
\text { system that supports the selection of the right cellphone and according } \\
\text { to the criteria of each user. A web-based decision support system for } \\
\text { the selection of mobile phones using the simple additive weighting }\end{array}$ \\
\hline $\begin{array}{l}\text { Keywords: } \\
\text { Decision Support System, } \\
\text { Mobile Phone, } \\
\text { SAW Method, }\end{array}$ & $\begin{array}{l}\text { method is a web-based information system that can be used to assist } \\
\text { prospective mobile phone buyers in choosing the right cellphone and } \\
\text { according to the criteria. In this system the user will give weight to the } \\
\text { main criteria, namely price, brand, depreciation, RAM, camera, screen, } \\
\text { battery, and features. The weighting must be with a total of } 100 \\
\text { percent. }\end{array}$ \\
\hline
\end{tabular}

This is an open access article under the $C C B Y-N C$ license.

\author{
Corresponding Author: \\ Agnesdea Meiti Suroso, \\ Program Studi Teknik Informatika, \\ Jurusan Teknik Informatika, \\ Fakultas Sains dan Teknologi, \\ Universitas Sanata Darma Yogyakarta \\ Email: dea.suroso@gmail.com
}

\section{Introduction}

The development of cellular technology that is getting faster and faster is a profitable thing for mobile phone distributors who offer various kinds of innovations. It is undeniable that the development of cellular technology has more or less influenced all aspects of human life, both in terms of social, economic and even political.

Developments in the telecommunications sector that have an impact on mobile phones can be seen from their physical form which is becoming lighter, thinner, colorful, to the operating system that offers attractive features that can be updated day by day and make it easier for humans to communicate, transact and even exchange information. In the past, before mobile phones developed as they are now, people did not think that using one device could do many things, such as talking or meeting face to face with someone who was far away or being able to read a newspaper that was usually purchased, subscribed and played games with that device or even transacted. like in a bank just by using a cellphone

The development of mobile phones in Indonesia is also growing rapidly so it is difficult to deny that the daily life of Indonesian people from various professions is very dependent on mobile phones. Problems arise when people do not only have one cellphone but more than one. This is because the need for communication is very high but it is not balanced with the existence of a system that supports the selection of the right cellphone and according to the criteria of each individual cellphone user. Many of mobile phone users only use easily accessible facilities such as search engines, cellphone 
tabloids or information from friends. This method is less effective in determining what mobile phones are in accordance with the criteria of prospective buyers.

Indonesian people who do not have sufficient knowledge related to information technology often feel confused when faced with these various choices, therefore sometimes they need information about cellphones to be purchased via the internet. On the internet they can find information about the cellphone but sometimes the information obtained is not fully in accordance with the needs, therefore a system is needed that can be easily accessed and does not confuse potential buyers and helps in making it easier to choose the right cellphone and according to the needs of the user.

Research conducted by Paramita (2013) with the title Effectiveness of using the simple additive weighting method in the decision support system for determining the provision of cash lending credit at PT. BPR X proves that this method is more effectively used in making credit decisions, so in writing this thesis a web-based decision support system will be made for the selection of mobile phones using the simple additive weighting method to help.

\section{Method}

\subsection{System Analysis}

In looking for information about the specifications of the cellphone that you want to buy, candidates usually buy using the manual method by looking at advertisements on TV, reading specifications in tabloids, seeing cellphones that are being widely used by people around the neighborhood or typing the name of the cellphone to be purchased on a search engine. google. The absence of a system that can assist in selecting the right cellphone and in accordance with the criteria makes it difficult to make decisions, therefore a decision support system for the selection of cellphones is needed that can assist users in determining the right cellphone and according to the user's criteria because the system provides several alternatives and criteria. .

\section{Results and Discussion}

\subsection{System Implementation}

At this stage the implementation must be in accordance with the database design that has been designed previously. The purpose of implementing the system is to implement the database design that has been designed into the system and then test the system. The implementation of the dialog management subsystem will explain the interface design of the system to be created. The interface design includes a home page, simulation page and alternative info page.

\section{a. Homepage}

This home page is made to make it easier for users to use the web according to the desired menu. There are two users on this web, namely administrator and user. In the home view above there is a home menu, calculations, about and login. There are also pictures of smartphones contained in the system database along with their descriptions.

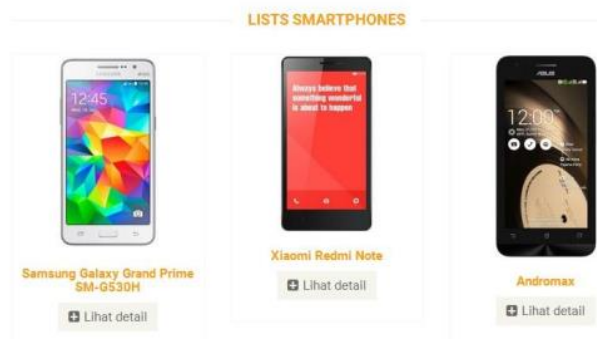

\section{b. Login Page}

Figure 1. Homepage

The login page contains a username and password that must be provided by the administrator if you want to access the administrator page. 


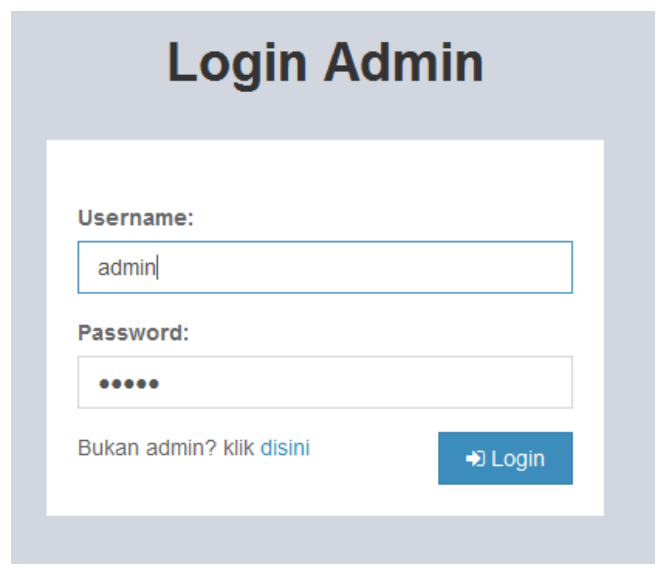

Figure 2. Login Page

\section{c. Admin Home Page}

The administrator's home page contains a criteria menu which contains sub-menus of criteria management and criteria value management, an alternative menu which contains sub-menus of alternative management and management of alternative values and a selection management menu. The home administrator displays the total criteria, the total criteria values, the total alternatives, the total alternative values and the total selection.

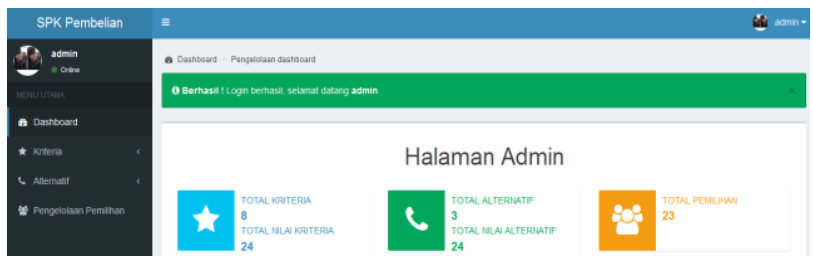

Figure 3. Admin Home Page

\section{d. Alternative Sub Management Page}

The alternative management page contains the number of alternatives, descriptions of these alternatives, descriptions of pictures and actions. There is also an add alternative button, view alternative values and delete it.

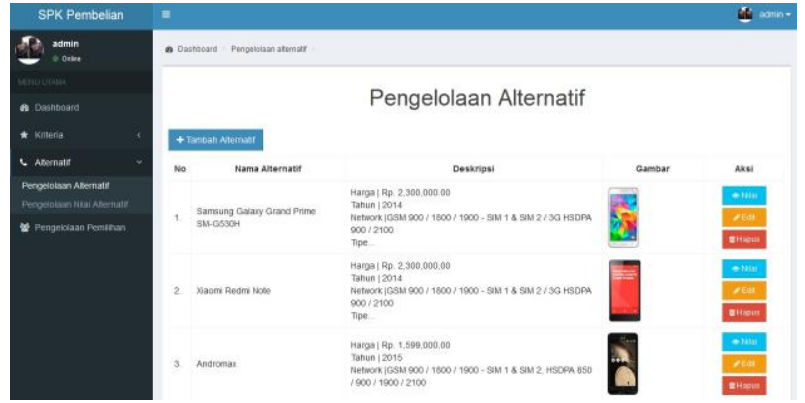

Figure 4. Alternative Sub Management Page

\section{e. Criteria Management Sub page}

The criteria management page displays the number of existing criteria and will be given a value of c, namely cost and b, namely benefit. There are also add, edit and delete buttons. 


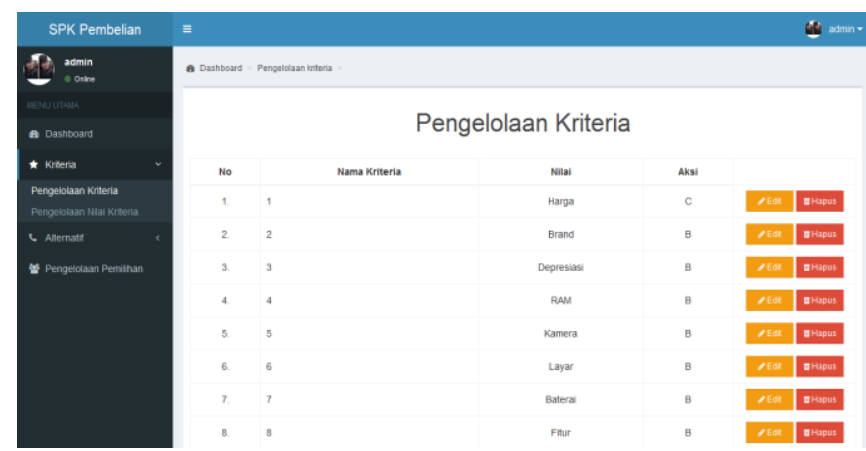

Figure 5. Criteria Management Sub page

\section{f. Sub-Page Value Management Criteria Standard}

The criteria standard value management page displays the name of the criteria, the contents of the standard, the standard values are 10, 5 and 1, there are also add, edit and delete buttons.

Pengelolaan Nilai Standar Kriteria

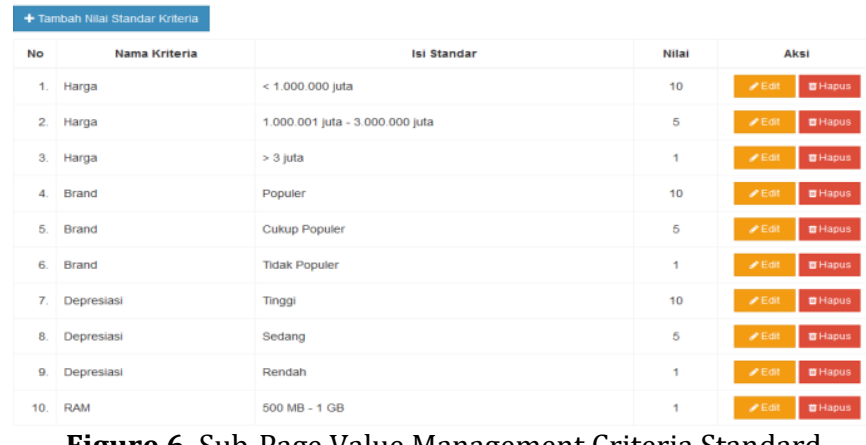

Figure 6. Sub-Page Value Management Criteria Standard

\section{g. Value Management Sub Page}

The value management page contains the number of alternatives, values and actions along with edit and delete buttons.

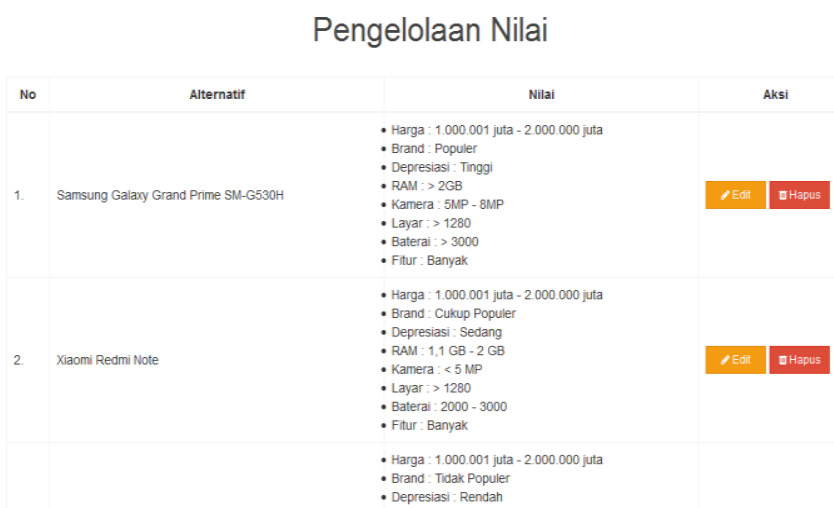

Figure 7. Value Management Sub-Page

\section{h. Value Management Sub Page}

The Add Alternative page serves to add the alternative desired by the user to be calculated using the SAW method. 


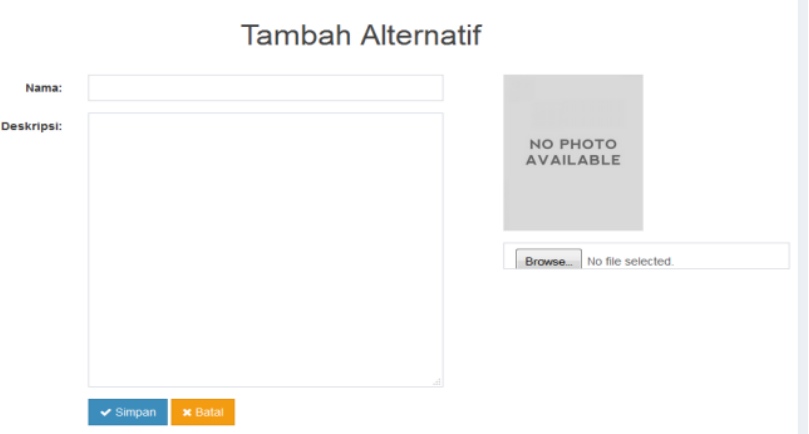

Figure 8. Value Management Sub-Page

\section{i. Alternative Edit Page}

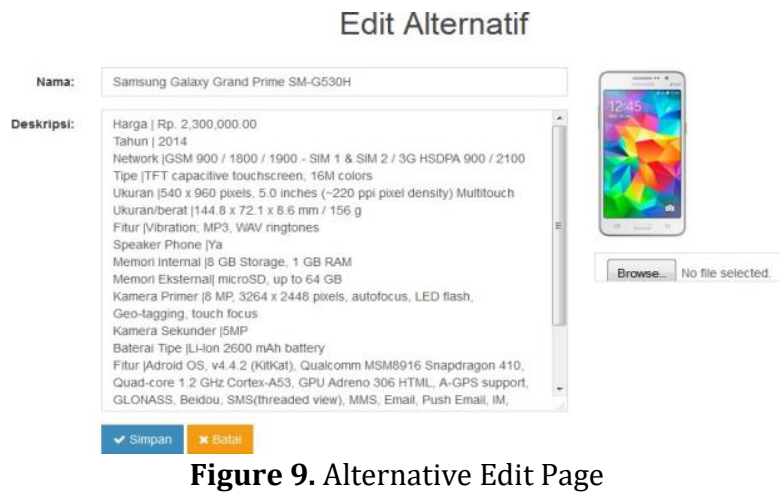

j. Alternative Delete Page

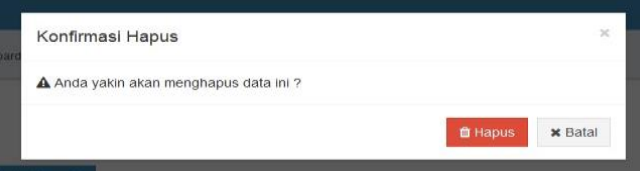

Figure 10. Alternative Delete Page

\section{k. Value Edit Page}

The value edit page contains images of alternatives and criteria that will be rated and then there are also save and cancel buttons.

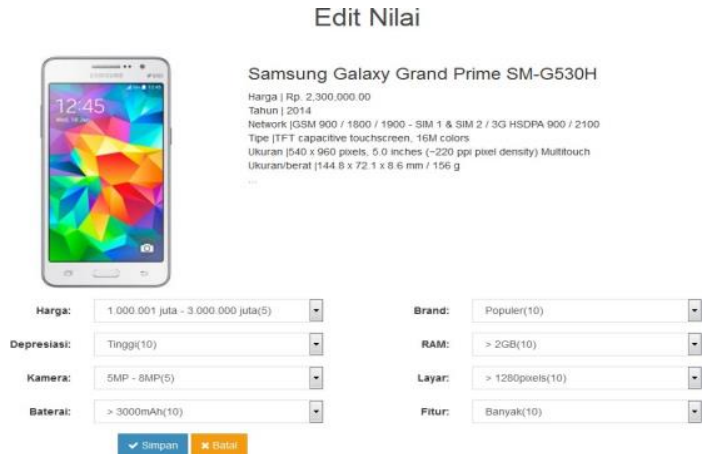

Figure 11. Value Edit Page 


\section{Delete Value Page}

The delete criteria value page is used to delete criteria values from the database.

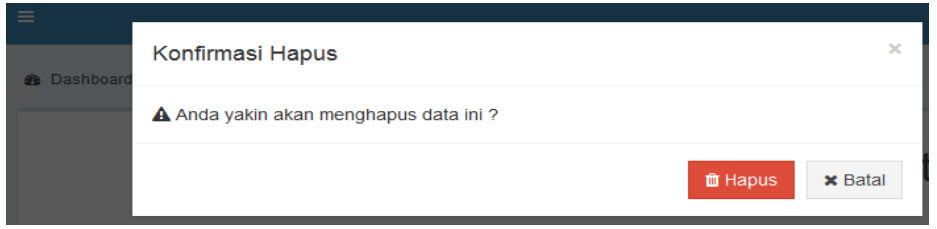

Figure 12. Delete Value Page

\section{m. Page Add Value Standard Criteria}

The Add Criteria Value page functions to increase the existing criteria values with values of 10, 5 and 1.

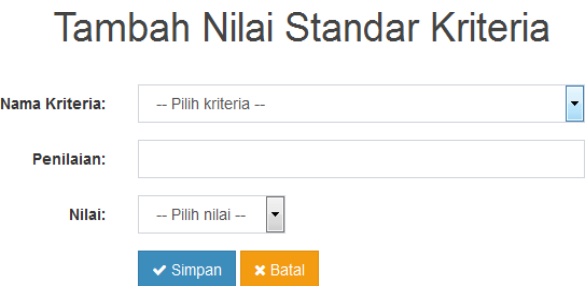

Figure 13. Page Add Value Standard Criteria

\section{n. Criteria Standard Value Edit page}

The criteria standard value edit page has a criteria name textbox that can be selected for editing, an assessment textbox, and a value that can be selected between one, five and ten. There is a save and cancel button.

\section{Edit Nilai Standar Kriteria}

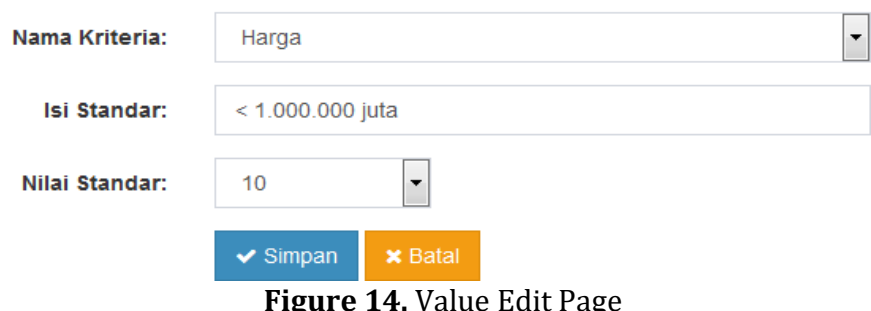

\section{o. Calculation Page}

The calculation page is made for the user to perform calculations based on the weights entered for each criterion. The weights entered must be added up to one hundred percent. 


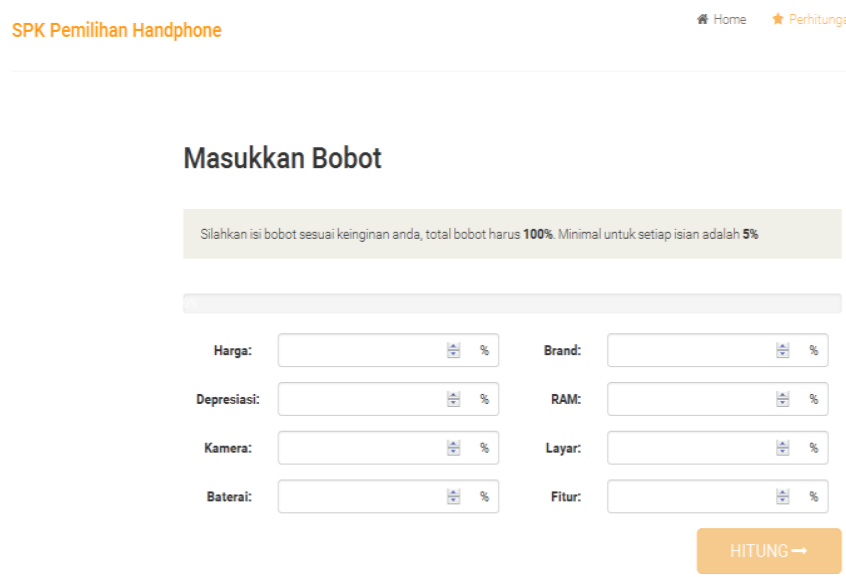

Figure 15. Calculation Page

\section{p. Results Page}

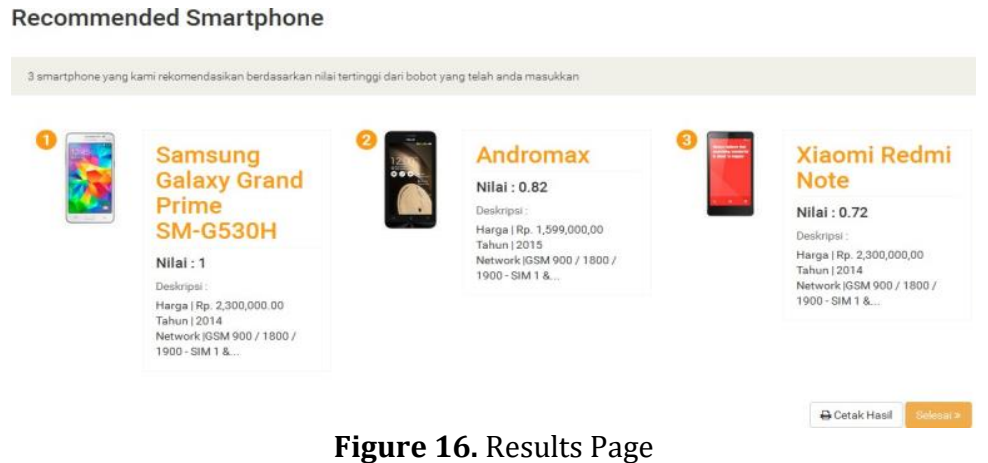

\section{Conclusion}

Based on the research and discussion above, it can be concluded that a web-based decision support system for the selection of mobile phones using the SAW (Simple Additive Weighting) method has been successfully created. Based on system testing, the system successfully displays the main menus, the validation message is successfully displayed, the addition of alternative data can be successfully added, changed or deleted and displays the print function of the calculation results. Meanwhile, the alternative user menu and criteria cannot be changed or added. This system can facilitate decision makers in making decisions based on priorities with the alternatives and criteria provided. The information generated by this system only displays the total assessment data from each alternative, regardless of which alternative is chosen. This system helps users determine the best mobile phone that is right and according to user needs faster than searching manually or in brochures. This system is still lacking in adding criteria because the criteria are only static.

\section{Reference}

Fishburn, P., C., 1967, Additive Utilities with Incomplete Product Set :Application to Priorities and Assigments, Operations Research Society of America (ORSA), Baltimor, MD, U.S.A.

Haedar, T., 1997. Prinsip-prinsip Networking Planning. PT. Gramedia. Jakarta.

Holloway, C.A, 1979. Decision Making Under Uncertainty: Models and Choice.Prentice-Hall, New Jersey.

Kusrini, 2006. Konsep dan Aplikasi Sistem Pendukung Keputusan. Penerbit Andi.

Kusumadewi, S.etal.2006. Fuzzy Multi-Attribute Decision Making (FUZZY MADM). Graha Ilmu.Yogyakarta. 
MacCrimmon, K. R., 1968, Decisionmaking among Multiple Attribute Alternatives. A Survey and Consolidated Approach, RM-4823-ARPA, the Rand Corporation, Santa Monica (CAL).

Mulyono, S., 1996. Teori Pengambilan Keputusan. Penerbit Fakultas Ekonomi Universitas Indonesia. Jakarta.

Moore, J. H. and M. G. Chang (1980). "Design of Decision Support Systems", Data Base 12(12).

Paramita, Dyah Ayu, 2013. Efektifitas penggunaan metode SAW (Simple Additive Weighting) dalam sistem pendukung keputusan penentuan pemberian kredit peminjaman uang tunai PT. BPR X. Perpustakaan Universitas Sanata Dharma.Yogyakarta.

Sprague, R. H. and Watson H. J., 1993. Decision Support Systems: Putting Theory Into Practice. Englewood Clifts, N. J., Prentice Hall

Suryadi, Kadarsah,2002, Sistem Pendukung Keputusan, Remaja Rosdakarya, Bandung.

Taha, H.A., 1982. Operations Research: an Introduction. New York: Macmillian.

Turban, Efraim., (1995). Decision Support and Expert System: Management Support System. Forth Edition. Prentice Hall International Inc. New Jersey.

Turban, Efraim dan Jaye Aronson. 1998. Decision Support Systems and Intelligent Systems. Fifth Edit ion. Prent ice-Hall, Inc.

Turban , Efraim \& Aronson, Jay E. 2001. Decision Support Systems and Intelligent Systems. 6th edition. Prentice Hall: Upper Saddle River, NJ. 